\title{
STUDENT WORKSHEET WITH AR VIDEOS: PHYSICS LEARNING MEDIA IN LABORATORY FOR SENIOR HIGH SCHOOL STUDENTS
}

\author{
Fauzi Bakri $(\mathbb{D}$, Handjoko Permana $(\mathbb{D})$, Suci Wulandari $(\mathbb{D}$, Dewi Muliyati $(\mathbb{D}$ \\ Universitas Negeri Jakarta (Indonesia) \\ fauri-bakri@unj.ac.id,bandjoko@unj.ac.id,suciwulandari284@gmail.com,dmuliyati@unj.ac.id
}

Received December 2019

Accepted March 2020

\section{Abstract}

Practicum based learning is required to provide opportunities for students in finding and applying concepts by observation. Student worksheets with a discovery learning model and equipped with AR video are needed as a learning tool, so students will be able to have good work in the laboratory and implementation of the practicum is effective. This study aims to produce LKPD (Lembar Kerja Peserta Didik or student worksheet) and AR (augmented reality) media that are videos related to the topic of practicum. The method used in this study is a research and development method with the Dick and Carey model approach. The feasibility test was carried out on the product using a Likert scale instrument. Feasibility test on media experts obtained a score of $89.95 \%$, on material experts, obtained a score of $96.93 \%$, on learning experts at $80 \%$ and obtained an average score of $88.96 \%$ with a very proper interpretation. Next, a user trial was conducted on the product with respondents, which are at 54th Senior High School in Jakarta. Trials on teachers obtained a score of $97.61 \%$, and trials on students obtained a score of $87.08 \%$. The limited trials are done by doing pre-test and post-test on students. Limited trial results obtained an average n-gain score of 0.46 . Based on the results of the feasibility test, user trials, and limited trials, it can be concluded that the developed student worksheet is very suitable to be used as a learning tool in physics practicum activities in Senior High School in 10th grade.

Keywords - Student worksheet, Augmented reality, Physics learning media.

\section{To cite this article:}

Bakri, F., Permana, H., Wulandari, S. \& Muliyati. D. (2020). Student worksheet with AR videos: Physics learning media in laboratory for Senior High School students. Journal of Technology and Science Education, 10(2), 231-240. https://doi.org/10.3926/jotse.891

\section{Introduction}

Physics is the base one of technology development. The study in physics requires a learning activity that provided opportunities for students to discover and apply the knowledge they obtain (Nugraha, Kaniawati, Rusdiana \& Kirana, 2016). Efforts to cultivate the skills of students can be done through practicum-based learning in the laboratory. Learning laboratory activities can train students' way of thinking and way of working (Siswono, 2017; Malik, Setiawan, Suhandi \& Permanasari, 2017). In laboratory activities, students are actively involved in the processes of observing the object, analyzing, proofing and concluding by themselves about the object or some processes (Nugraha, Utari, Saepuzaman 
\& Nugraha, 2018; Malik, Setiawan, Suhandi, Permanasari \& Sulasman, 2018; Kustijono, Jatmiko \& Ibrahim, 2018).

In laboratory activities, student worksheets required as a learning guidance tool that make the activities can be done well. Student worksheet in science learning is needed to develop by the teacher based on learning approach, method, and models so that activities are more directed and structured and able to direct students to find new concepts in learning (Fitriana, Yusuf \& Susanti, 2016; Riyadi, Ertikanto \& Suyatna, 2018). The discovery learning model is one of the learning models that support practicum-based scientific learning that can be applied in the student worksheet. The discovery learning model allows students to build their own knowledge based on data or information obtained through observation (Kustijono et al., 2018; Wartono, Batlolona \& Grusche, 2018). Other research states, student worksheets with discovery learning models can guide students to think critically, innovatively and work independently (Sulistia, 2017; Fitriani, Bakri \& Sunaryo, 2017; Azizah, Dafik \& Susanto, 2018).

In addition to developing technology, studying physics also involves technologies that developed, Augmented Reality (AR) is one of them. AR creates a real object by bridging the virtual and the real world (Wang, Zhang, Xue \& Cai, 2018). AR has been used in education to improve the quality of learning (Cai, Wang \& Chiang, 2014; Chiu, Dejaegher \& Chao, 2015; Rexa, 2018; Hapsari, Mutiara \& Handayani, 2015; Bakri, Pratiwi \& Muliyati, 2019). AR attachment in the media learning can be used to practice the higher-order thinking skills (Bakri, Ervina \& Muliyati 2019; Bakri, Sumardani \& Muliyati, 2019). AR packaging in the form of instructional videos of 3-5 minutes duration related to the topic of practicum can provide an overview of the practicum to be carried out and can improve the ability of students to work in the laboratory (Nadelson, 2015; Akçayır, Akçayır, Pektaş \& Ocak, 2016). Based on the explanation above, so this research is developing student worksheets with AR videos for learning physics in the laboratory.

\section{Design/Methodology/Approach}

The study is the research and development method with the Dick \& Carey model approach. This selection is following the statement of Borg \& Gall that the educational development model that can be used is the development model of Dick \& Carey (Gall et al., 2003). The Dick and Carey model consists of 10 steps, but this research is limited up to the eighth step (Dick, Carey \& Carey, 2015). The steps of this research are: analyzing the need to identify general objectives, analyze learning, analyze characteristics of students, formulating specific learning goals, developing assessment instruments, developing learning strategies, develop products in the form of student worksheet and AR applications, carry out validation, and revising the product. Product development is carried out in the basic physics laboratory and digital media laboratory, Universitas Negeri Jakarta. Product validation is carried out by three experts; media experts, material experts, and learning experts. The product through a limited trial at 54th Senior High School Jakarta.

\section{Result and Discussions}

\subsection{Student Worksheet with the Discovery Learning Model}

The result of the student worksheet focused on the Material and Unit Quantities with the practicum title "Measurement". Figure 1 shows the front, inside and back cover of the student worksheet. The front cover contains the student worksheet title, student worksheet designation, the name of the author, the logo of the agency, and illustrations that illustrate the topics contained in the student worksheet. The inside cover contains the title of the material, practical illustrations, and basic competencies that must be achieved. The back cover contains a synopsis of the whole contents.

A student worksheet is arranged in three stages, namely the preliminary stage, the practicum stage, and the post-practicum stage. A student worksheet is arranged by the discovery learning model based on concept discovery. The steps of the activities compiled in student worksheets are presented in Table 1. 


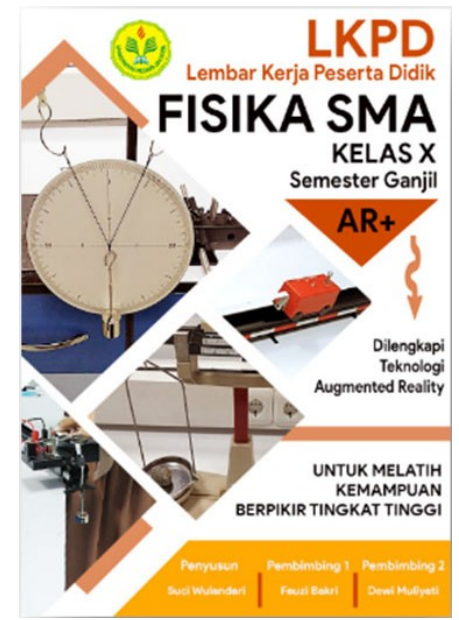

(a)

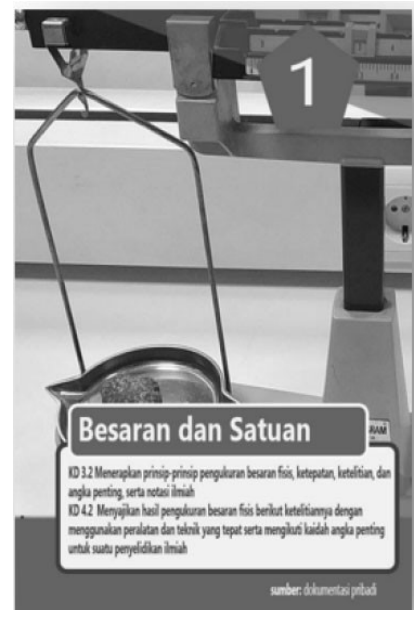

(b)

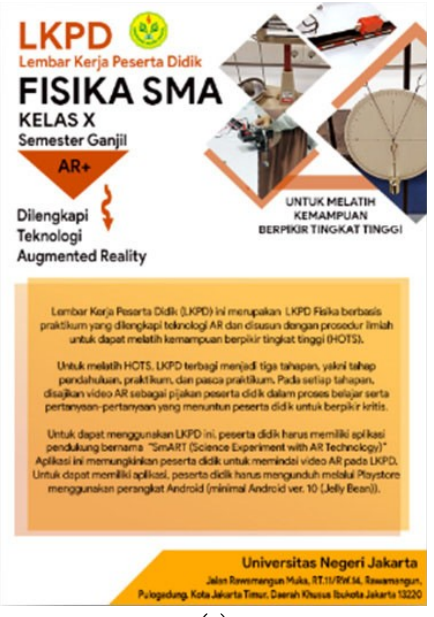

(c)

Figure 1. The cover view (a) front cover, (b) inside cover, (c) back cover of the student worksheet

\begin{tabular}{|c|c|c|}
\hline Syntax/Step & Display & Activity \\
\hline \multicolumn{3}{|c|}{ Preliminary stage } \\
\hline Preliminary & 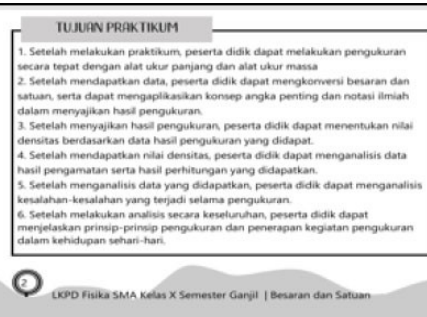 & $\begin{array}{l}\text { Students read and understand the learning } \\
\text { objectives which must succeed through } \\
\text { practical activities. }\end{array}$ \\
\hline \multirow[b]{2}{*}{ Stimulation } & 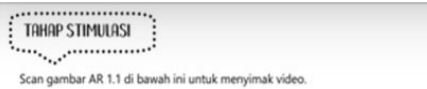 & \\
\hline & 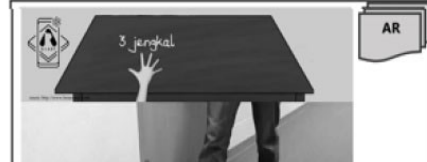 & $\begin{array}{l}\text { Students watch AR videos that appear after } \\
\text { being scanned. Students are asked to criticize } \\
\text { the video and answer questions related to the } \\
\text { video in the initial questions section. }\end{array}$ \\
\hline \begin{tabular}{|l|} 
Problem \\
statement
\end{tabular} & 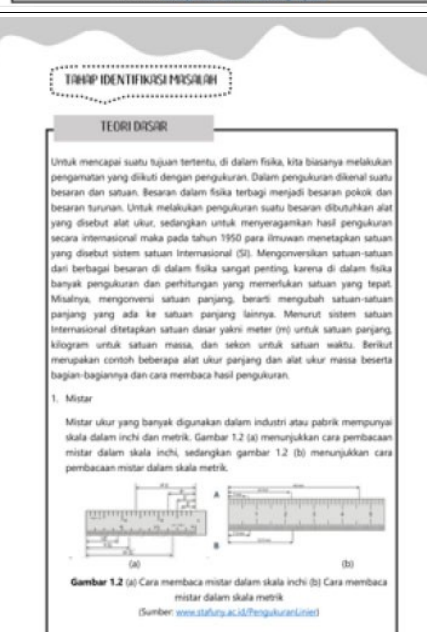 & $\begin{array}{l}\text { To support students' understanding of the } \\
\text { concepts to be learned, this student } \\
\text { worksheet is equipped with information on } \\
\text { basic theories that are expected to help } \\
\text { students find concepts. }\end{array}$ \\
\hline
\end{tabular}




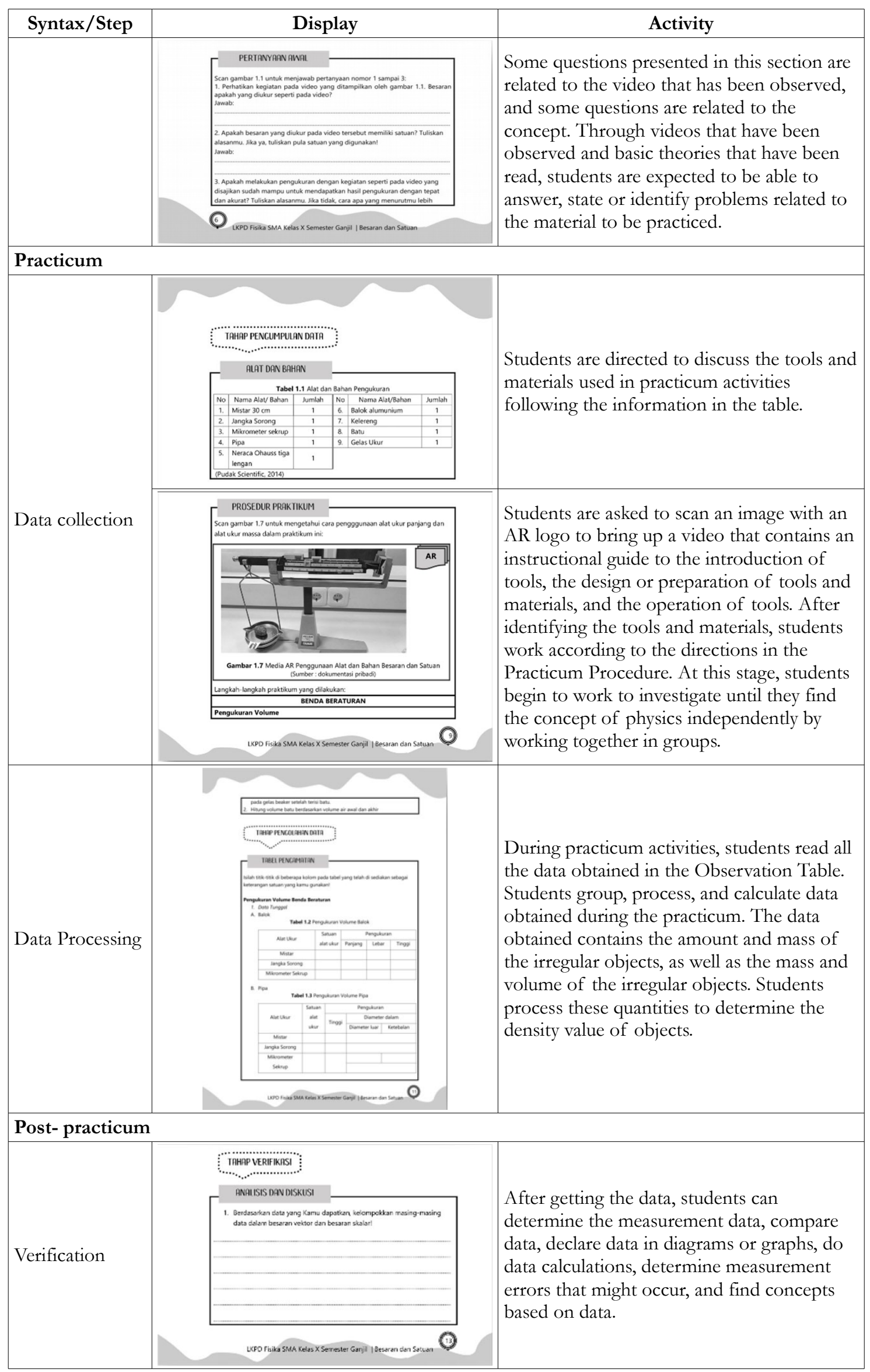




\begin{tabular}{|l|l|}
\hline Syntax/Step & \multicolumn{1}{|c|}{ Activity } \\
\hline Generalization & $\begin{array}{l}\text { After analyzing the data by discussion, } \\
\text { students are directed to make conclusions } \\
\text { related to the measurement concepts } \\
\text { obtained through practicum activities. }\end{array}$ \\
\hline
\end{tabular}

Table 1. The steps of discovery learning in the student worksheet

\subsection{AR Video}

To be able to use AR, a minimum Android smartphone device v.4.0 (Jelly Bean) is required with an application called "Science Experiments with AR Technology (SmART)" installed. Figure 2 shows the viewing of the SmART application.

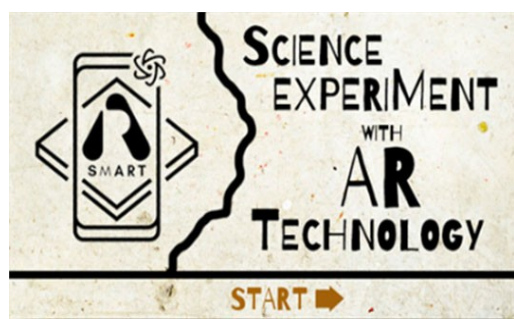

(a)

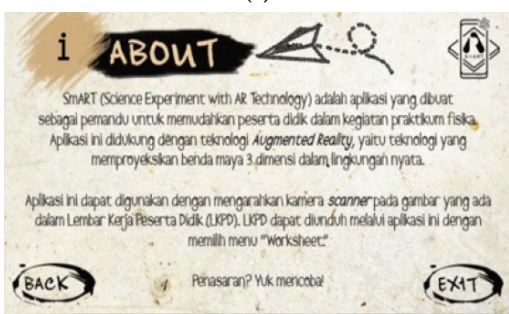

(d)

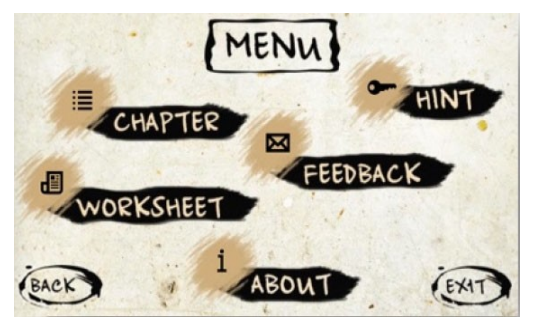

(b)

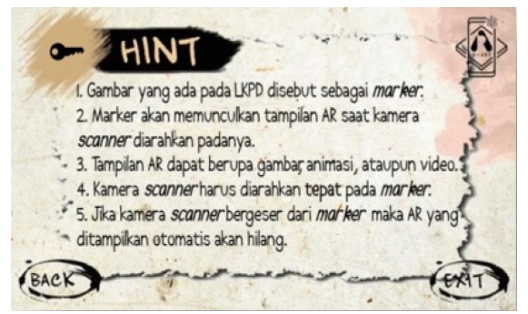

(e)

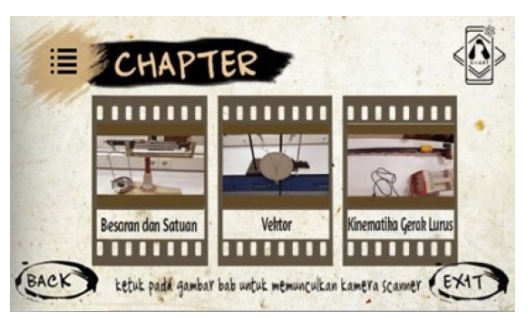

(c)

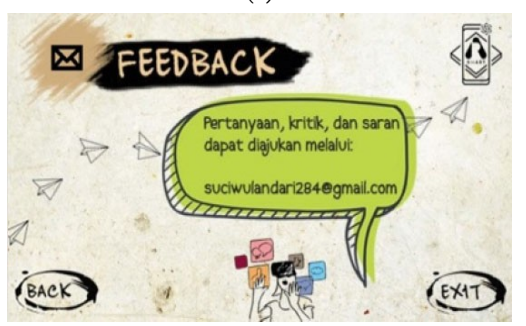

$(\mathrm{f})$

Figure 2. (a) start page, (b) menu page, (c) chapter main page, (d) about page, (e) hint page, (f) feedback page 
AR videos can be raised by scanning images called markers. The scan is done by activating the SmART application camera namely on the Chapter Page, Magnitude, and Unit menu. The marker image is included in the student worksheet with the AR mark in the upper right of the image. The video display that appears on the smartphone screen of the students is arranged so that the video can be paused, played back and forth, or played repeatedly, shown in Figure 3.

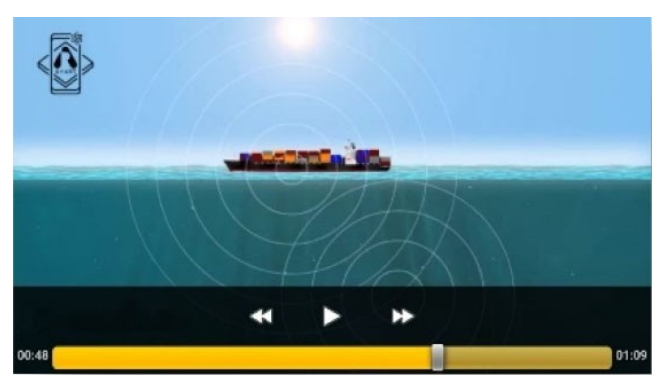

Figure 3. Video display that appears on the smartphone screen after scanning the marker

The video obtained in this student worksheet returns as many as three; located in the introduction, core, and cover. Each video has a duration of $+2-5$ minutes. AR video display presented at the student worksheet is discussed in Table 2 .

\begin{tabular}{|c|c|c|c|}
\hline \multicolumn{4}{|c|}{ Material: Vector } \\
\hline \multicolumn{4}{|c|}{ Topic of practicum: The result of force vectors } \\
\hline \multicolumn{2}{|c|}{ Total image } & \multicolumn{2}{|l|}{10} \\
\hline \multicolumn{2}{|c|}{ Total marker } & 3 & \\
\hline \multicolumn{2}{|c|}{ Total videos } & 3 & \\
\hline No & Object name & Marker & The process of making in Unity \\
\hline 1 & $\begin{array}{l}\text { Push the car } \\
\text { and paddle }\end{array}$ & $1 \mathrm{Ar}$ & (4) \\
\hline
\end{tabular}

Purpose: The video serves as an apperception so that students understand the concept of values and direction on force, and the movement in the phenomenon of pushing cars and rowing on white water rafting.

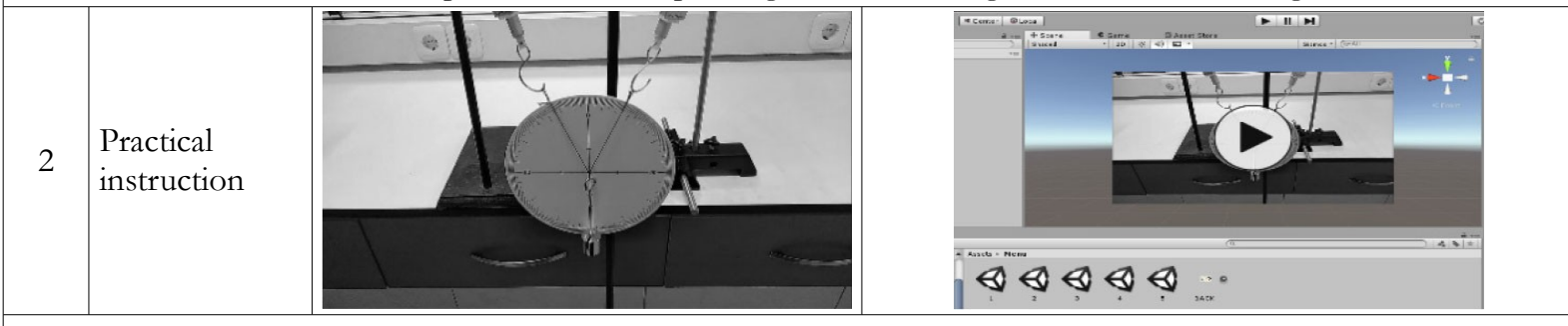

Purpose: Students can recognize tools and materials and know how to assemble these tools and materials.

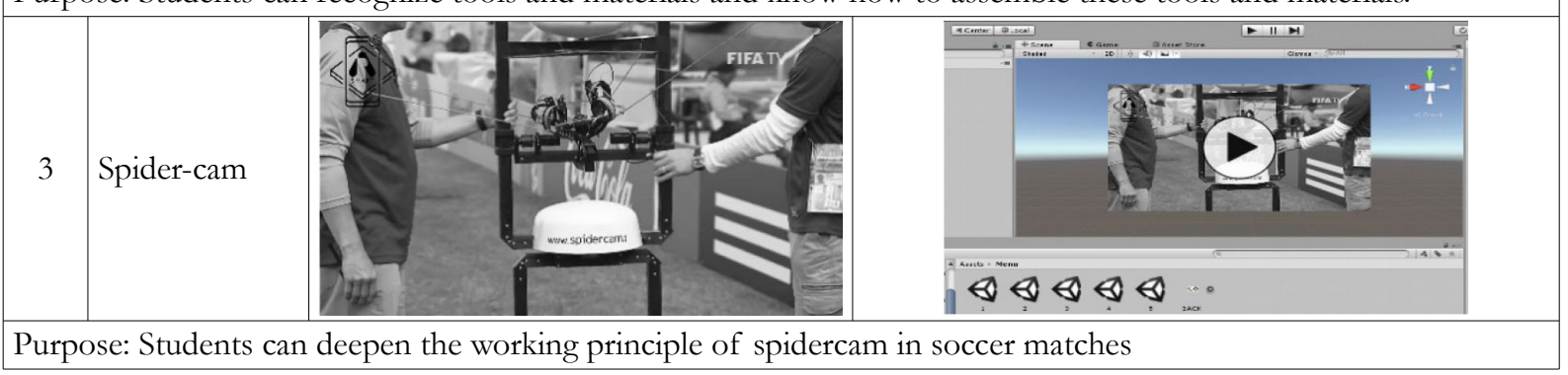

Table 2. The details of video AR 


\subsection{Formative Evaluation Test}

The student worksheet and AR video developed have passed the feasibility test or validation by media experts, material experts, and learning experts. The results of validation by experts are shown in Table 3.

\begin{tabular}{|c|l|c|c|}
\hline \multicolumn{1}{|c|}{ Aspects Measured } & Presentation Score & Interpretation \\
\hline Media Expert Validation & $93.85 \%$ & Very Good \\
\hline 1 & Cover size & $100.00 \%$ & Very Good \\
\hline 2 & Cover layout & $80.00 \%$ & Very Good \\
\hline 3 & Cover typography & $96.00 \%$ & Very Good \\
\hline 4 & Component of the student worksheet & $85.71 \%$ & Very Good \\
\hline 5 & Layout of worksheet & $84.00 \%$ & Very Good \\
\hline 6 & Typography of contents & $80.00 \%$ & Very Good \\
\hline 7 & Illustration of contents & $100.00 \%$ & Very Good \\
\hline 8 & Interface of AR & $90.00 \%$ & Very Good \\
\hline 9 & Function of AR & $89.95 \%$ & Very Good \\
\hline Average of all aspects & & Very Good \\
\hline Material Expert Validation & $93.85 \%$ & Very Good \\
\hline 1 & Material content & $100.00 \%$ & Good \\
\hline 2 & Writing Language & $96.93 \%$ & Good \\
\hline Average of all aspects & $80.00 \%$ & Good \\
\hline Learning Expert Validation & $80.00 \%$ & Good \\
\hline 1 & Didactic aspect & $80.00 \%$ & $0.00 \%$ \\
\hline 2 & Construction aspect & & \\
\hline 3 & Technical aspect & & \\
\hline Average of all aspects & & \\
\hline
\end{tabular}

Table 3. The validation results of media experts and learning materials

Based on the results of media validation, an average score of $89.95 \%$ was obtained with a very decent interpretation. It means, student worksheet and AR video developed are following the standard both in terms of size, layout, and typography, the color mix presented is also good, the illustrations that are displayed are following the practicum context and the SmART application that is developed functions well and can be integrated with student worksheet. Suggestions and input delivered by media experts is an improvement in the sound quality of the video. Based on the results of the material validation, an average score of $96.93 \%$ was obtained with a very decent interpretation. The material presented is considered to be by scientific principles, contains mathematical equations needed to help students, accompanied by illustrations that can clarify the material and is presented in a communicative and effective language. Based on the results of learning validation, an average score of $80 \%$ is obtained with a proper interpretation. According to learning experts, the language used in student worksheet is following the level of thinking of students, the illustrations that are presented are already appropriate, and the syntax/steps of the learning model of discovery learning are visible. Suggestions/input provided by learning experts are examples of pictures and cases presented in basic theory are contextual examples, the discovery learning syntax is included in writing in student worksheet and is marked on each subtitle, and brief information about ar is presented at the front of the student worksheet.

After the feasibility/validation test was carried out, the student worksheet was tested on the user, the physics teacher and X MIPA 3 students at $54^{\text {th }}$ Senior High School in Jakarta. The results of the user trial are stated in Table 4. 


\begin{tabular}{|c|l|c|c|}
\hline No. & \multicolumn{1}{|c|}{ Aspects Measured } & Presentation Score & Interpretation \\
\hline User trial (teacher) & $93.33 \%$ & Very Good \\
\hline 1 & Material Content & $100.00 \%$ & Very Good \\
\hline 2 & Display and Typography & $97.14 \%$ & Very Good \\
\hline 3 & Writing Language & $100.00 \%$ & Very Good \\
\hline 4 & Augmented Reality (AR) & $97.61 \%$ & Very Good \\
\hline Average of all aspects & & Very Good \\
\hline User trial (students) & $88.33 \%$ & Very Good \\
\hline 1 & Display of student worksheet & $85.00 \%$ & Very Good \\
\hline 2 & Content of student worksheet & $81.67 \%$ & Very Good \\
\hline 3 & Function of AR & $93.33 \%$ & Very Good \\
\hline 4 & Interface AR & $87.08 \%$ & \\
\hline Average of all aspects & &
\end{tabular}

Table 4. User Trial Results (Teachers and Students)

Based on the results of product trials by users, a score of $97.61 \%$ obtained by teachers in the field of Physics studies with a very decent interpretation. Student worksheet products and AR videos produced have fulfilled teacher satisfaction both from the appropriate material aspects, aspects of appearance, typography, linguistic, and the appearance of smart and AR video applications. Suggestions and input delivered are accuracy in typing agar. Based on the results of product trials by students, a score of $87.08 \%$ was obtained with very proper interpretation. Students consider that based on the student worksheet display, the contents of the student worksheet, the SmART application display, and the functioning of the application, the product developed is very interesting and is a new experience for students. However, students become less interested because the student worksheet text that is presented is in black and white.

After the product has been validated by an expert and tested by the user, then a revision is made to the product based on the advice and input provided. After a revision, the product is ready to be tested on a limited basis. To assess the success rate of product development, measurement is done by giving a pre-test post-test to students in the limited trial. Before the pre-test and post-test are carried out, the items that will be used as measurement instruments are first tested for eligibility. The feasibility of the problem through 4 types of tests, namely: Validity test, reliability test, difficulty level test, and different power test. As for the results of limited trials conducted on students of class X MIPA 3, an average gain score of 0.46 with a pre-test score of 3.25 and a post-test score of 6.34 from a maximum score of 10.00. Based on this gain score, it can be interpreted that there is an increase in knowledge for students in the medium category. The gain score obtained is not in the high category can occur due to several factors, one of which is due to the use of student worksheets with AR videos that have not been intensive in practicum-based learning and students who are still adapting to learning systems equipped with AR media. However, overall, it can be concluded that the student worksheet developed with AR video is very feasible to use for learning physics in the laboratory.

\section{Discussion by Comparing with Other Result}

Learning media related to the use of AR consists of video instruction in practicum-based learning conducted by Akçayır et al. (2016) discusses the use of AR technology with objects forming videos, animations, and simulations about the skills and attitudes of students in the laboratory. The object created is related to the topic of physics practicum. The research method used was a quasi-experiment with the control class and the experimental class. This research is conducted periodically for five weeks. The results obtained show how using AR significantly improves student skills in the laboratory. Visualization of the objects presented can help students in practicum and no longer needs to be done manually in the laboratory. They memorize the components and agree to the implementation instructions based on the video agreed by the instructor. When carrying out the practicum, students can carry out the practicum more quickly and need more the role of the teacher or laboratory assistant. 
Based on this, an AR video for practicum-based learning is provided, which is integrated with worksheets and compiled using a learning discovery learning model so that students can work more optimally in the laboratory.

\section{Conclusions}

Formative evaluation results show that the Physics Students Worksheet developed with Augmented Reality technology for odd semester X grade high school students has met the criteria in terms of material, media, and learning so that it is declared very feasible to be used as physics teaching material.

\section{Declaration of Conflicting Interests}

The authors declared no potential conflicts of interest with respect to the research, authorship, and publication of this article.

\section{Funding}

We gratefully acknowledge funding support from the Hibah Penelitian Terapan Unggulan Perguruan Tinggi 2019 - LPPM Universitas Negeri Jakarta under the contract number 51/SP2H/DRPM/LPPM-UNJ/III/2019. Our simulations developed in the Digital Laboratory - Physics Education Department, Universitas Negeri Jakarta.

\section{References}

Akçayır, M., Akçayır, G., Pektaş, H.M., \& Ocak, M.A. (2016). Augmented reality in science laboratories: The effects of augmented reality on university students' laboratory skills and attitudes toward science laboratories. Computers in Human Behavior, 57, 334-342. https://doi.org/10.1016/j.chb.2015.12.054

Azizah, S.N., Dafik, D., \& Susanto, S. (2018). The Effectiveness of Discovery Based Learning Implementation through Improving Students' Innovative thinking Skills in solving Open-Ended Task of Pattern Generalization. International Journal of Advanced Engineering Research and Science, 5(8). https://doi.org/10.22161/ijaers.5.8.10

Bakri, F., Ervina, E., \& Muliyati, D. (2019). Practice the higher-order thinking skills in optic topic through physics worksheet equipped with augmented reality. AIP Conference Proceedings, 2169(1), 020006. AIP Publishing. https://doi.org/10.1063/1.5132641

Bakri, F., Pratiwi, S., \& Muliyati, D. (2019). Video-enriched worksheet based on augmented reality technology: The heat experiment is easier. AIP Conference Proceedings, 2169(1), 020010. AIP Publishing. https://doi.org/10.1063/1.5132645

Bakri, F., Sumardani, D., \& Muliyati, D. (2019). Integrating augmented reality into worksheets: Unveil learning to support higher-order thinking skills. AIP Conference Proceedings, 2169(1), 020012. AIP Publishing. https://doi.org/10.1063/1.5132647

Cai, S., Wang, X., \& Chiang, F.K. (2014). A case study of Augmented Reality simulation system application in a chemistry course. Computers in human behavior, 37, 31-40. https://doi.org/10.1016/j.chb.2014.04.018

Chiu, J.L., DeJaegher, C.J., \& Chao, J. (2015). The effects of augmented virtual science laboratories on middle school students' understanding of gas properties. Computers \& Education, 85, 59-73. https://doi.org/10.1016/j.compedu.2015.02.007

Dick, W., Carey, L., \& Carey, J.O. (2015). The systematic design of instruction (8th ed.). New York: Pearson, 6-8

Fitriana, D., Yusuf, M., \& Susanti, E. (2016). Pengembangan Lembar Kerja Siswa Menggunakan Pendekatan Saintifik Untuk Melihat Berpikir Kritis Siswa Materi Perbandingan. Jurnal Pendidikan Matematika, 10(2), 23-38. https://doi.org/10.22342/jpm.10.2.3629.23-38

Fitriani, W., Bakri, F., \& Sunaryo, S. (2017). Pengembangan lembar kerja siswa (lks) fisika untuk melatih kemampuan berpikir tingkat tinggi (high order thinking skill) siswa SMA. Jurnal Wabana Pendidikan Fisika, 2(1), 36-42. https://doi.org/10.17509/wapfi.v2i1.4901 
Gall, M.D., Gall, J.P., \& Borg, W.R. (2003). Educational research: An introduction (7th ed.). Boston, MA: Allyn \& Bacon, 570

Hapsari, G.I., Mutiara, G.A., \& Handayani, R. (2015). Perancangan dan Implementasi Modul Praktikum. Jurnal Infotel, 7(1), 23-28. https://doi.org/10.20895/infotel.v7i1.26

Kustijono, R., Jatmiko, B., \& Ibrahim, M. (2018). The Effect Of Scientific Attitudes Toward Science Process Skills In Basic Physics Practicum By Using Peer Model. International Journal Of Geomate, 15(50), 82-87. https://doi.org/10.21660/2018.50.IJCST50

Malik, A., Setiawan, A., Suhandi, A., \& Permanasari, A. (2017). Enhancing pre-service physics teachers' creative thinking skills through hot lab design. AIP Conference Proceedings, 1868(1), 070001. AIP Publishing. https://doi.org/10.1063/1.4995177

Malik, A., Setiawan, A., Suhandi, A., Permanasari, A., \& Sulasman, S. (2018). HOT Lab-Based Practicum Guide for Pre-Service Physics Teachers. IOP Conference Series: Materials Science and Engineering, 288(1), 012027. IOP Publishing. https://doi.org/10.1088/1757-899X/288/1/012027

Nadelson, L.S., Scaggs, J., Sheffield, C., \& McDougal, O.M. (2015). Integration of video-based demonstrations to prepare students for the organic chemistry laboratory. Journal of Science Education and Technology, 24(4), 476-483. https://doi.org/10.1007/s10956-014-9535-3

Nugraha, M.G., Kaniawati, I., Rusdiana, D., \& Kirana, K.H. (2016). Combination of inquiry learning model and computer simulation to improve mastery concept and the correlation with critical thinking skills (CTS). AIP Conference Proceedings, 1708(1), 070008. AIP Publishing. https://doi.org/10.1063/1.4941181

Nugraha, M.G., Utari, S., Saepuzaman, D., \& Nugraha, F. (2018). Redesign of students' worksheet on basic physics experiment based on students' scientific process skills analysis in Melde's law. Journal of Physics: Conference Series, 1013(1), 012038. IOP Publishing. https://doi.org/10.1088/17426596/1013/1/012038

Riyadi, B., Ertikanto, C., \& Suyatna, A. (2018). The analysis and design of guided inquiry e-worksheet Based to develop high order thinking skills. International Journal of Research-Granthaalayah, 6(7), 223-233.

Siswono, H. (2017). Analisis Pengaruh Keterampilan Proses Sains Terhadap Penguasaan Konsep Fisika Siswa. Momentum: Physics Education Journal, 1(2), 83-90. https://doi.org/10.21067/mpej.v1i2.1967

Sulistia, H. (2017). Pengembangan lembar kerja peserta didik (LKPD) fisika berbasis discovery learning pada materi elastistas dan hukum hooke untuk kelas XI SMA. Edu Fisika.

Rexa, B.T. (2018). Pengembangan Lembar Kerja Siswa (LKS) Berbasis Augmented Reality Pada Model Pembelajaran Project Based Learning Di SMK N 2 Lamongan. IT-EDU, 3(01).

Wang, T., Zhang, H., Xue, X., \& Cai, S. (2018). Augmented reality-based interactive simulation application in double-slit experiment. Online Engineering \& Internet of Things, 701-707. https://doi.org/10.1007/978-3319-64352-6_66

Wartono, J.T., Batlolona, J. R., \& Grusche, S. (2018). Inquiry-Discovery Empowering High Order Thinking Skills And Scientific Literacy On Substance Pressure Topic. Jurnal Ilmiah Pendidikan Fisika AlBiRuNi, 07(2), 139-151. https://doi.org/10.24042/jipfalbiruni.v7i2.2629

Published by OmniaScience (www.omniascience.com)

Journal of Technology and Science Education, 2020 (www.jotse.org)

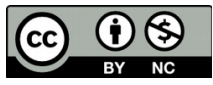

Article's contents are provided on an Attribution-Non Commercial 4.0 Creative commons International License. Readers are allowed to copy, distribute and communicate article's contents, provided the author's and JOTSE journal's names are included. It must not be used for commercial purposes. To see the complete licence contents, please visit https://creativecommons.org/licenses/by-nc/4.0/. 